\title{
Mice deficient in the C-terminal domain of TAR DNA-binding protein 43 develop age- dependent motor dysfunction associated with impaired Notch1-Akt signaling pathway
}

Kohei Nishino ${ }^{1,2+}$, Seiji Watanabe ${ }^{1,2+}$, Jin Shijie ${ }^{1,2}$, Yuri Murata ${ }^{1,2}$, Kotaro Oiwa ${ }^{1,2}$, Okiru Komine ${ }^{1,2}$, Fumito Endo ${ }^{1,2}$, Hitomi Tsuiji ${ }^{3}$, Manabu Abe ${ }^{4}$, Kenji Sakimura ${ }^{4}$, Amit Mishra ${ }^{5}$ and Koji Yamanaka ${ }^{1,2^{*}}$ (D)

\begin{abstract}
Intracellular mislocalization of TAR DNA-binding protein 43 (TDP-43), a nuclear DNA/RNA-binding protein involved in RNA metabolism, is a pathological hallmark of amyotrophic lateral sclerosis (ALS). Although the aggregationprone, TDP-43 C-terminal domain is widely considered as a key component of TDP-43 pathology in ALS, recent studies including ours suggest that TDP-43 N-terminal fragments (TDP- $\triangle C$ ) may also contribute to the motor dysfunction in ALS. However, the specific pathological functions of TDP-43 N-terminal fragments in mice have not been elucidated. Here, we established TDP- $\triangle C$ knock-in mice missing a part of exon 6 of murine Tardbp gene, which encodes the C-terminal region of TDP-43. Homozygous TDP- $\triangle C$ mice showed embryonic lethality, indicating that the N-terminal domain of TDP-43 alone is not sufficient for normal development. In contrast, heterozygous TDP- $\triangle C$ mice developed normally but exhibited age-dependent mild motor dysfunction with a loss of C-boutons, large cholinergic synaptic terminals on spinal a-motor neurons. TDP- $\triangle C$ protein broadly perturbed gene expression in the spinal cords of aged heterozygous TDP- $\triangle C$ mice, including downregulation of Notch $1 \mathrm{mRNA}$. Moreover, the level of Notch1 mRNA was suppressed both by TDP-43 depletion and TDP- $\triangle C$ expression in Neuro2a cells. Decreased Notch 1 mRNA expression in aged TDP- $\triangle C$ mice was associated with the age-dependent motor dysfunction and loss of Akt surviving signal. Our findings indicate that the N-terminal region of TDP-43 derived from TDP- $\Delta C$ induces the age-dependent motor dysfunction associated with impaired Notch1-Akt axis in mice.
\end{abstract}

Keywords: Amyotrophic lateral sclerosis (ALS), TAR DNA-binding protein 43 (TDP-43), Motor dysfunction, TDP-43 knock-in mice, Notch1, Akt

\section{Introduction}

Amyotrophic lateral sclerosis (ALS) is an adult-onset neurodegenerative disease characterized by a progressive loss of upper and lower motor neurons in the spinal cord, brain stem, and cerebral cortex, leading ultimately

\footnotetext{
* Correspondence: kojiyama@riem.nagoya-u.ac.jp

${ }^{\dagger}$ Kohei Nishino and Seiji Watanabe contributed equally to this work. 'Department of Neuroscience and Pathobiology, Research Institute of Environmental Medicine, Nagoya University, Chikusa-ku, Nagoya, Aichi 464-8601, Japan

${ }^{2}$ Department of Neuroscience and Pathobiology, Graduate School of Medicine, Nagoya University, Nagoya, Aichi 466-8550, Japan Full list of author information is available at the end of the article
}

to fatal skeletal muscle paralysis [37]. Aberrant accumulation of TAR DNA-binding protein 43 (TDP-43) is a pathological hallmark of ALS and frontotemporal lobar degeneration (FTLD) [2, 24]. TDP-43 contains a canonical nuclear localization signal, and thus is predominantly localized in nuclei. However, in ALS patients, TDP-43 is partially or completely escaped from the nuclei of motor neurons and glial cells, where it forms cytoplasmic inclusion bodies. Therefore, there may be the combined pathomechanisms of a loss of nuclear TDP-43 function and a gain of cytosolic TDP-43 mediated toxicities [33]. 
TDP-43 is a ubiquitously expressed DNA/RNAbinding protein shuttling between nucleus and cytoplasm, and plays a critical role in multiple aspects of RNA metabolism such as splicing, stability, transport, translation, and microRNA maturation [5, 27]. TDP43 has two RNA binding motifs (RRM1 and RRM2, respectively) in its amino (N)-terminal domain (a.a. 1273). TDP-43 also possesses a prion-like domain with a glutamine and asparagine $(\mathrm{Q} / \mathrm{N})$ rich region in the carboxyl (C)-terminus (a.a. 274-414) that confers susceptibility to form aggregates [36]. Missense mutations in the gene encoding human TDP-43, TARDBP, have been identified in familial and sporadic ALS, suggesting that TDP-43 dysfunction leads to motor neuron degeneration [16, 33, 37].

Most known ALS-linked TDP-43 mutations are located in the C-terminal domain $[16,37]$. In addition, cleaved TDP-43 C-terminal fragments are accumulated in the lesion of ALS patients [2, 24, 35], and indeed are core components of TDP-43 cytoplasmic inclusions and aggregates [11, 25, 35]. Moreover, we previously reported that aberration of the C-terminal domain disrupted spliceosomal integrity [34]. Therefore, the C-terminal domain of TDP-43 is tightly associated with the ALS pathology. In addition to the $\mathrm{C}$-terminal fragments, the $\mathrm{N}$-terminal fragments of TDP-43 have also been found in the postmortem spinal cord of ALS patients [46]. In the cited study, the N-terminal fragments were produced by the action of calpain, reduced solubility, and sequestered full-length TDP-43 into cytoplasmic aggregates. Intriguingly, another study reported that the alternatively spliced endogenous TDP-43 S6 short variant devoid of the C-terminal domain formed highly insoluble cytoplasmic and nuclear inclusions reminiscent of TDP-43 pathology in ALS [31]. These results suggest that TDP- $43 \mathrm{~N}$-terminal fragments may also be involved in TDP-43 pathology. However, the precise pathological mechanisms of TDP- $43 \mathrm{~N}$-terminal fragments still remains to be elucidated.

To examine the role of $\mathrm{N}$-terminal TDP-43 fragments in vivo, we established TDP- $\Delta \mathrm{C}$ knock-in mice (TDP- $\Delta \mathrm{C}$ mice), in which Tardbp gene region encoding the $\mathrm{C}$-terminal domain (a part of exon6) is eliminated. Heterozygous TDP- $\Delta C$ mice exhibited mild age-dependent motor dysfunction with a loss of C-boutons, large cholinergic synaptic terminals on motor neurons, and suppression of Notch1-Akt signaling. Suppression of Notch1 mRNA was induced both by TDP-43 depletion and TDP- $\Delta C$ expression. Collectively, these results suggest that $\mathrm{N}$-terminal fragments of TDP-43 also contribute to ALS pathology associated with impaired Notch1-Akt signaling pathway.

\section{Materials and methods}

\section{Animals}

Murine Tardbp genomic DNA was isolated from C57BL/6 N mouse. The gene targeting vector was designed to replace a part of its exon 6 , encoding amino acid 274-414 of murine TDP-43, with $3 \times$ FLAG tag to delete C-terminal portion of TDP-43. We used the genomic fragment spanning from exon 2 to intron 5 and the fragment of 3 '-UTR of exon 6 (both the arms are approximately $6 \mathrm{~kb}$ ) for constructing targeting vectors, respectively. A neomycin resistant gene $\left(\right.$ neo $\left.^{r}\right)$ gene cassette with FRT sequences and diphtheria toxin (DTA) cassette were also inserted for positive and negative selection, respectively. The gene targeting was performed by using embryonic stem (ES) cells derived from C57BL/6 N (RENKA) as described elsewhere [19]. The correctly targeted ES cells were microinjected into the blastocysts to generate chimeric mice. The mice heterozygous for TDP- $\Delta \mathrm{C}$ mutant allele were maintained in $\mathrm{C} 57 \mathrm{BL} / 6 \mathrm{~J}$ genetic background, and genotyped by PCR using following primers: 5'-GGCAAACAGCAGTTCACTTTCACCC3', 5'-GCTGCTGCTGACTACAAAGACC-3', and 5' AGATTTGGTGGTAATCCAGGTGGC-3'. The mice were housed in the specific pathogen free (SPF) environment $\left(12 \mathrm{~h}\right.$ light-dark-cycle; $23 \pm 2{ }^{\circ} \mathrm{C} ; \quad 50 \pm 10 \%$ humidity), and treated in compliance with the requirements of the Animal Care and Use Committee, Nagoya University.

\section{Rotarod test}

Rotarod tests were performed as previously reported [44]. In brief, the mice were placed on the rotating rods, which accelerated from 0 to $30 \mathrm{rpm}$ for 5 min with 15 min interval among each trial (Muromachi Kikai, Tokyo Japan). The longest latencies to fall off the rotating rods out of three trials were scored. No randomization or blinding was used in this study.

\section{Antibodies}

Following primary antibodies were used in this study: anticholine acetyl transferase (ChAT) (1:100, \#AB144P, Merck Millipore Corp., Billerica, MA, USA), anti-Kv2.1(K89/34) (1:100, \#75-014, RRID: AB_10673392, Neuromab, USA), anti-TDP-43(3H8) (1:2,000 for immunofluorescence, 1:1, 000 for immunoblotting, \#MABN45, Merck Millipore) anti-TDP-43(A260) (1:1,000, \#3449, RRID: AB_2200511, Cell Signaling Technology, Danvers, MA), anti-FLAG M2 (1:5,000, \#F1804, RRID: AB_262044, Sigma-Aldrich Co LLC, St. Louis, MO, USA), anti-glial fibrillary acidic protein (GFAP) (1:250, \#G3893, RRID: AB_477010, SigmaAldrich), anti-Iba1 (1:500, \#019-10741, Wako Pure Chemical Industries Ltd., Osaka, Japan), anti-fibrillarin (1:1,000, \#2639, RRID: AB_2278087, Cell Signaling), anti-heat shock 
protein 110 (Hsp110) (1:1,000, \#SPA-1101E, RRID: AB 916878, Enzo Life Sciences Inc., Farmingdale, NY), antiphospho Akt (Ser473) (1:1,000, \#4060, RRID: AB_2315049, Cell Signaling), anti-pan Akt (1:1,000, \#4691, RRID: AB_ 915783, Cell Signaling), anti- $\beta$-actin (1:5,000, \#A5441, RRID: AB_476744, Sigma-Aldrich). Anti-TDP-43 (N-terminal) was raised against a chemically synthesized N-terminal peptide of human TDP-43 a.a. 1-10 conjugated to keyhole limpet hemocyanin $(\mathrm{KLH})$, and rabbit sera following the immunization was used at 1:200 for immunoblotting.

\section{Immunofluorescence}

Immunofluorescence analyses were performed as described elsewhere $[43,44]$. Briefly, mice at indicated age were deeply anesthetized, and transcardially perfused with phosphate buffered saline (PBS) then $4 \%(\mathrm{w} / \mathrm{v})$ paraformaldehyde in $0.1 \mathrm{M}$ phosphate buffer for $10 \mathrm{~min}$, respectively. After the incubation with $30 \%(\mathrm{w} / \mathrm{v})$ sucrose in PBS, the dissected lumbar spinal cords were embedded in Tissue-Tek OCT compound medium (Sakura Finetek, Tokyo, Japan), and frozen at $-80^{\circ} \mathrm{C}$ until use. After blocking, the $12 \mu \mathrm{m}$-sliced spinal cord sections were incubated with primary antibodies for overnight at $4{ }^{\circ} \mathrm{C}$. Bound primary antibodies were detected with Alexa Fluor 488-conjugated anti-mouse or Alexa Fluor 546conjugated anti-goat IgG secondary antibodies (both used in 1:1000) (Thermo Fisher Scientific Inc., Waltham, MA, USA). Immunofluorescence images were obtained by a confocal laser scanning microscopy (LSM-700; Carl Zeiss AG, Oberkochen, Germany) and the equipped software (Zen; Carl Zeiss AG). Cholinergic large synaptic terminals on $\alpha$-motor neurons (C-boutons) were identified as contacting sites of ChAT and Kv2.1 on the surface of ChAT-positive motor neuron soma in ventral lumber spinal cords. For quantification, more than 50 motor neurons in three animals per genotype were counted for C-boutons based on the immunofluorescence images obtained by confocal laser scanning microscopy.

\section{Plasmids, cell culture, and transfection}

The full-length or $\Delta C$ (a.a. 1-273) human TDP-43 cDNA was inserted into pEGFP-N1 vector (Takara Bio, Shiga, Japan) using seamless ligation cloning extract (SLiCE) $[20,51]$ from Escherichia coli HST02 (Takara Bio) to express with C-terminal EGFP tag. Site-directed mutagenesis on TDP-43 cDNA was performed according to the instruction of QuikChange site-directed mutagenesis kit (Stratagene, La Jolla, CA, USA). Mouse neuroblastoma Neuro2a (RRID: CVCL_0470) cells were maintained in Dulbecco's Modified Eagle's' Medium (DMEM) containing $4.5 \mathrm{~g} / \mathrm{L}$ glucose supplemented with $10 \%(\mathrm{v} / \mathrm{v})$ fetal bovine serum (FBS), $100 \mathrm{U} / \mathrm{mL}$ penicillin, and $100 \mu \mathrm{g} / \mathrm{mL}$ streptomycin (all from Thermo Fisher) at $37^{\circ} \mathrm{C}$ in a humidified chamber containing $5 \% \mathrm{CO}_{2}$. The cells were differentiated in DMEM supplemented with $2 \%(\mathrm{v} / \mathrm{v})$ FBS and $2 \mathrm{mMN6}, 2^{\prime}$-O-dibutyryladenosine-3',5'- cyclic monophosphate (Nacalai Tesque, Kyoto, Japan) for indicated times. Transfection was performed using Lipofectamine 2000 reagent according to the manufacturer's instruction (Thermo Fisher).

\section{RNA isolation and quantitative reverse transcription (RT)- PCR}

Total RNA of mouse spinal cords was isolated with Trizol reagent (Ambion, Austin, TX, USA), followed by further purification using RNeasy Mini Kit (Qiagen, Hilden, Germany) according to the manufacturer's instruction. The concentration of total RNA was determined by a spectrophotometer (NanoDrop ND-2000; Thermo Fisher), and RNA quality was assessed with the RNA integrity determined by microfluidics-based capillary electrophoresis (RNA integrity number (RIN) $\geqq 8.0$ ) (Bioanalyzer 2100; Agilent Technologies, Palo Alto, CA, USA). cDNA was synthesized from $1 \mu \mathrm{g}$ of the purified RNA using PrimeScript II 1st strand Synthesis Kit (Takara Bio) and an oligo- $(\mathrm{dT})_{15}$ primer. Quantitative reverse transcription (RT)-PCR was performed using SYBR Premix Ex Taq II (Takara Bio) according to the manufacturer's protocol in Thermal Cycler Dice Real Time System II (Takara Bio). Relative mRNA expression was calculated by standard curve method normalized to $\beta$-actin gene $(A c t b)$ and relative to the control samples. All samples were run in duplicate. The primers that were used in this study are listed as follows:

for specific detection of mRNA levels of endogenous wild-type TDP-43; 5'-AAAAGGAAAATGGATGAGAC AGATG-3' and 5'-AACTGAGCAGGATCTGAAAGAC TATTT-3', for quantifying mRNA levels of both TDP- $\triangle \mathrm{C}$ and endogenous wild-type TDP-43; 5'-ATGATAAGGTTG CCCAGTC-3' and 5'-TACTGTTACCAAACCCACC-3', for Notch1; 5' -TGGATGACCTAGGCAAGTC-3' and 5'TTCTGCATGTCCTTGTTGG-3', for Hes1; 5'-TGCCAG CTGATATAATGGAG-3' and 5'-CTTTGATGACTTTC TGTGCTC-3', for Pten; 5'-AAGGGAGTCACAATTC CCA-3' and ' 5'-ACTGAGGATTGCAAGTTCC-3', for quantifying mRNA levels of $\beta$-actin; $5^{\prime}$-GCTATGTTGCTC TAGACTTCG-3' and ' 5'-GGATTCCATACCCAAGAA GG-3'.

\section{Subcellular fractionation}

Tissues were fractionated as previously reported [4] with slight modifications. A frozen tissue was homogenized in ice-cold homogenization buffer (10 mM HEPES, 250 $\mathrm{mM}$ sucrose, $0.4 \%(\mathrm{v} / \mathrm{v})$ phenylmethylsulfonyl fluoride (PMSF), pH 7.4) supplemented with protease inhibitor cocktail (Roche Diagnostics, Basel, Switzerland) using 
Potter-Elvehjem homogenizer (Wheaton Industries, Millville, NJ, USA). The homogenate was centrifuged at $600 \times \mathrm{g}, 4^{\circ} \mathrm{C}$ for $5 \mathrm{~min}$. The supernatant was centrifuged at $10,000 \times \mathrm{g}, 4{ }^{\circ} \mathrm{C}$ for $30 \mathrm{~min}$, and discard the pellet. The supernatant was further centrifuged at $18,000 \times \mathrm{g}, 4^{\circ} \mathrm{C}$ for $30 \mathrm{~min}$, and the resultant supernatant was collected as a cytosolic fraction. The pellet of the first centrifugation step $(600 \times \mathrm{g})$ was resuspended in ice-cold hypotonic buffer (10 mM HEPES, $10 \mathrm{mM} \mathrm{KCl,} 1 \mathrm{mM} \mathrm{MgCl}_{2}, 0.5 \mathrm{mM}$ dithiothreitol (DTT), 0.4\%(v/v) PMSF, pH 7.4), and incubate for $15 \mathrm{~min}$ on ice. After centrifugation at $600 \times \mathrm{g}$, $4{ }^{\circ} \mathrm{C}$ for $5 \mathrm{~min}$, the pellet was resuspended in ice-cold hypertonic buffer (10 mM HEPES, $400 \mathrm{mM} \mathrm{NaCl}, 1 \mathrm{mM}$ $\mathrm{MgCl}_{2}, 0.2 \mathrm{mM}$ ethylene glycol tetraacetic acid (EGTA), $30 \%(\mathrm{v} / \mathrm{v})$ glycerol, $0.5 \mathrm{mM}$ DTT, $0.4 \%(\mathrm{v} / \mathrm{v})$ PMSF, pH 7.4), and incubated for $30 \mathrm{~min}$ at $4{ }^{\circ} \mathrm{C}$ with gentle agitation to induce osmotic shock. After centrifugation at 18, $000 \times \mathrm{g}, 4^{\circ} \mathrm{C}$ for $30 \mathrm{~min}$, the resultant supernatant was collected as a nuclear fraction.

\section{Immunoblotting}

Tissues from control or TDP- $\Delta \mathrm{C}$ mice were sonicated in ice-cold lysis buffer (50 mM Tris- $\mathrm{HCl}, 150 \mathrm{mM} \mathrm{NaCl}, 1$ $\mathrm{mM}$ ethylenediaminetetraacetic acid (EDTA), 1\%(v/v) Triton X-100) supplemented with protease inhibitor cocktail (Roche). The lysates were centrifuged at 15, $000 \times \mathrm{g}, 4^{\circ} \mathrm{C}$ for $5 \mathrm{~min}$ to remove insoluble debris. Total protein concentration was measured using Bio-rad protein assay kit as described in manufacturer's instructions (Bio-rad, Hercules, CA, USA). Aliquots of $20 \mu \mathrm{g}$ proteins were analyzed by sodium dodecyl sulfate- polyacrylamide electrophoresis (SDS-PAGE), and transferred to a polyvinylidene difluoride membrane (Immobilon-P, Merck Millipore). After blocking with 2\% Bovine Serum Albumin (BSA) in TBS-T $(50 \mathrm{mM}$ Tris- $\mathrm{HCl}, 150 \mathrm{mM}$ $\mathrm{NaCl}, 0.5 \%(\mathrm{v} / \mathrm{v})$ Tween-20, $\mathrm{pH} 7.4)$, the membrane was incubated with the primary antibodies diluted in TBS (50 mM Tris- $\mathrm{HCl}, 150 \mathrm{mM} \mathrm{NaCl}, \mathrm{pH} 7.4$ ), followed by incubation with horseradish peroxidase (HRP)-conjugated anti-rabbit (1:5,000, \#NA934, RRID: AB_772206, GE Healthcare, Waukesha, WI, USA) or anti-mouse (1: 5,000, \#NA931, RRID: AB_772210, GE Healthcare) secondary antibodies. The membranes were visualized with Immobilon Crescendo Western HRP substrate (\#WBLUR0100, Merck Millipore) according to the manufacturer's protocol. Densitometric analyses were performed by using an image analyzer LAS-4000 mini (Fuji-film, Tokyo, Japan) with the equipped software (Multi Gauge; Fuji-film).

\section{Microarray analysis}

Microarray analyses were performed using purified total RNA of the 700 days-old TDP- $\Delta C$ mouse spinal cords or their littermate non-transgenic controls. cRNAs were prepared using Low Input Quick-Amp Labeling Kit (Agilent) according to the manufacturer's instruction, and were hybridized with mouse SurePrint G3 mouse GE microarray $8 \times 60 \mathrm{~K}$ Ver.2.0 chips (Agilent). Data were subsequently normalized and analyzed using GeneSpring 13.0 software (Agilent). Pathway analyses were conducted using the Single Experiment Pathway analysis feature in GeneSpring 13.0 (Agilent). The moderated ttest was utilized, and 1.2-fold cut-off value was used to select significantly changed transcripts.

\section{Statistics}

Time-course of rotarod score was analyzed by two-way ANOVA and Mann-Whitney non-parametric u-test. All the data from immunofluorescence, semi-quantitative immunoblotting and quantitative RT-PCR were analyzed by an unpaired $t$-test, for comparison between 2 groups, or one-way ANOVA followed by the post-hoc Tukey's multiple comparison $t$-test, for comparison among more than 3 groups, respectively. All the statistical analyzes were carried out using GraphPad Prism software (GraphPad Software, La Jolla, CA).

\section{Results}

Generation of the mice deficient in the TDP-43 C-terminal domain by gene targeting

The previous studies identified various N-terminal TDP43 fragments with different length of the remaining Cterminal domain produced by the calpain-dependent cleavage $[46,47]$. Among the TDP-43 mutants devoid of various length of $\mathrm{C}$-terminal domains, we found that complete deletion of the C-terminal domain from TDP43 produced most severe neurotoxicity in cultured neuronal cells (Additional file 1: Figure S1). Therefore, to examine pathogenic roles of TDP- $43 \mathrm{~N}$-terminal fragments in vivo, we generated the mice completely deficient in the TDP-43 C-terminal domain by gene targeting. A part of exon 6 encoding the murine TDP-43 C-terminal domain (a.a. 274-414) was deleted (Fig. 1a). Mice heterozygous for the TDP- $\Delta \mathrm{C}$ mutant allele were successfully generated (Fig. 1b). When we crossbred the heterozygous mice (TDP- $\Delta \mathrm{C}$ mice) to produce offspring, the ratio of the number of born heterozygous mice to the one of wild-type was roughly 2:1 (heterozygous: 21, wild-type: 9), however no homozygous mice were born, indicating an embryonic lethality of TDP- $\Delta C$ homozygous mouse as observed in TDP-43 deficient mice. In contrast, TDP- $\Delta \mathrm{C}$ mice, heterozygous for a TDP- $\Delta \mathrm{C}$ allele, were developed normally. The level of endogenous wild-type TDP-43 mRNA was not altered in the spinal cords of TDP- $\triangle \mathrm{C}$ mice compared to the one in the wildtype (WT) controls (Fig. 1c), likely due to TDP-43 autoregulation mediated by the intact 3 '-UTR. On the other hand, the total expression level of endogenous TDP- 

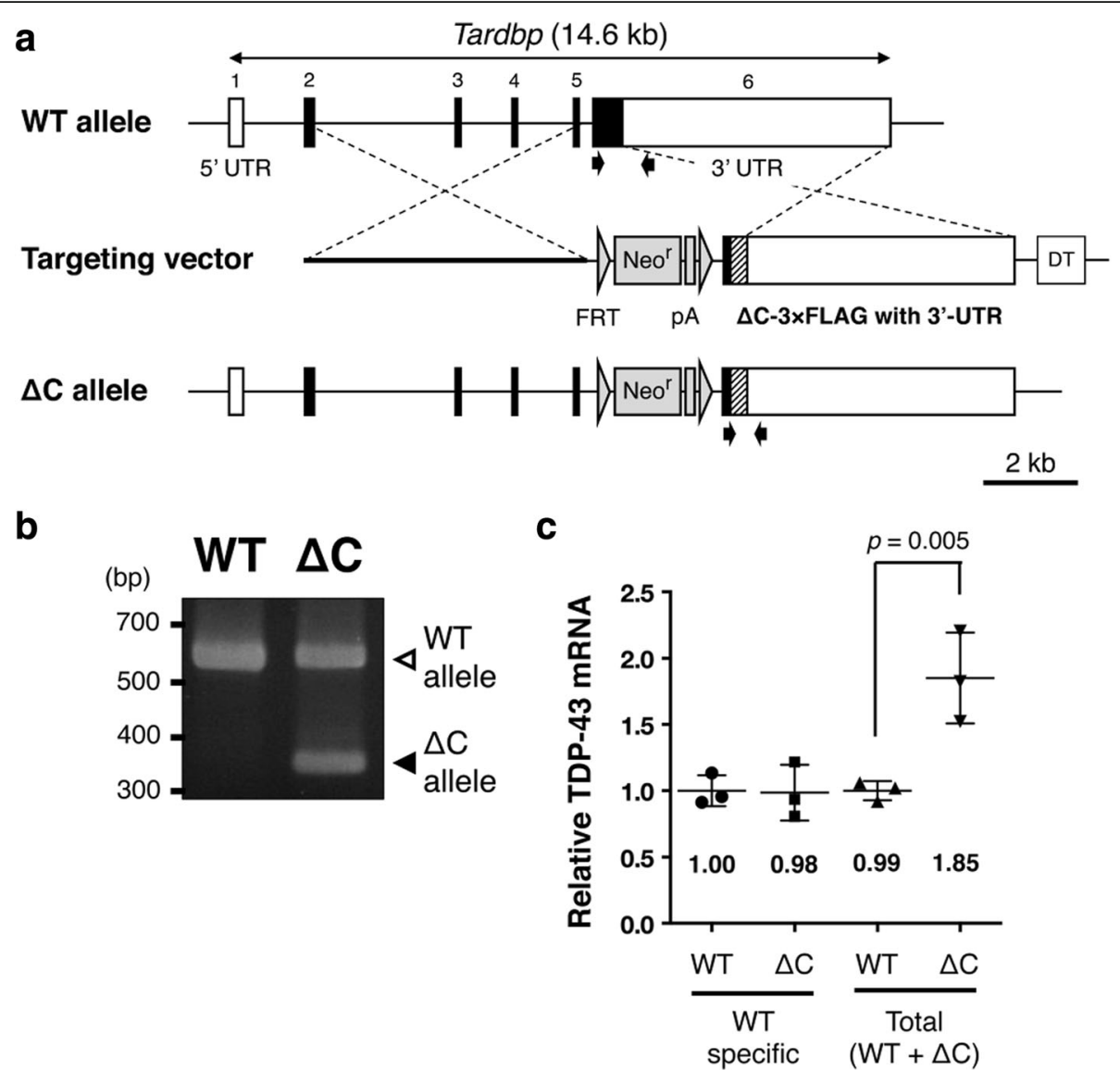

Fig. 1 Generation of TDP- $\triangle C$ knock-in mouse. a Schematic diagrams of the murine Tardbp gene locus, the gene targeting vector for TDP- $\triangle C$ knock-in, and the resulting TDP- $\triangle C$ allele after homologous recombination. A region encoding the C-terminal domain of murine TDP-43 (a.a. $274-$ 414) in Tardbp exon 6 was replaced with a $3 \times$ FLAG tag coding sequence. A neomycin resistance gene (Neo') flanked by FRT sequences inserted into the intron 5 and a diphtheria toxin (DT) cassette inserted downstream of intron 6 were used for positive and negative selection, respectively. 3'-UTR, which is crucial for autoregulation of TDP-43 mRNA, remained intact. $\mathbf{b}$ Representative image for genotyping of wild-type (WT) and heterogeneous TDP- $\triangle C$ knock-in $(\triangle C)$ mice. Specific primers used for PCR are indicated by arrows in (a). $\mathbf{c}$ mRNA levels of TDP-43 and TDP- $\triangle C$ in the spinal cord (SC) of WT and $\triangle C$ mice. Quantitative reverse transcription PCR (RT-PCR) was performed with "WT specific" primers, recognizing only endogenous TDP-43 (TDP-WT) cDNA and "total" primers, recognizing both TDP-WT and TDP- $\triangle C$ cDNAs. Relative mean of TDP-43 mRNA levels normalized to the WT control are plotted with standard deviation (SD). The level of TDP-WT mRNA did not differ between WT and $\triangle C$ mice, therefore, the expression level of TDP- $\triangle C$ mRNA was almost the same as the endogenous TDP-43 mRNA

43 plus TDP- $\Delta \mathrm{C}$ mRNAs in TDP- $\Delta \mathrm{C}$ mice was almost twice as high as TDP-43 mRNA expression in WTs (Fig. 1c), indicating that TDP- $\triangle \mathrm{C}$ mRNA expressed at levels similar to endogenous TDP-43 mRNA in TDP- $\triangle \mathrm{C}$ mice.

TDP- $\Delta C$ protein is enriched in cytosol, and less stable than the wild-type TDP-43

In TDP- $\Delta \mathrm{C}$ mice, the expression pattern of TDP- $\Delta \mathrm{C}$ proteins across various tissues including the central nervous system was similar to the one of wild-type TDP-43 protein (Fig. 2a, b). To assess the subcellular localization of TDP- $\Delta$ C protein in the mouse spinal cord, we immunostained lumbar spinal cord sections using an antibody against the endogenous TDP-43 (anti-TDP-43 (3H8), a mouse monoclonal antibody recognizing the TDP-43 C- terminal region) or an anti-FLAG antibody specifically recognizing (FLAG-tagged) TDP- $\Delta \mathrm{C}$ protein (Fig. 2a, Additional file 1: Figure S2). TDP- $\Delta$ C protein, visualized by the anti-FLAG antibody, was localized both in the cytosol and nucleus of spinal motor neurons (Fig. 2c, upper panels), and did not affect the localization of endogenous wild-type TDP-43 (Fig. 2c, lower panels). Subcellular fractionation of TDP- $\Delta \mathrm{C}$ mouse spinal cords revealed that TDP- $\Delta C$ protein was predominantly localized in cytosol (Fig. 2d). Although the mRNA level of TDP- $\Delta C$ was almost the same as endogenous TDP-43 mRNA (Fig. 1c), the steady-state level of TDP- $\Delta$ C protein was much less than that of endogenous TDP-43 (Fig. 2e, f). While, the level of endogenous TDP-43 was not altered between TDP- $\Delta \mathrm{C}$ mice and controls (Fig. 2e, g). These results suggest that TDP- $\Delta \mathrm{C}$ protein is much 


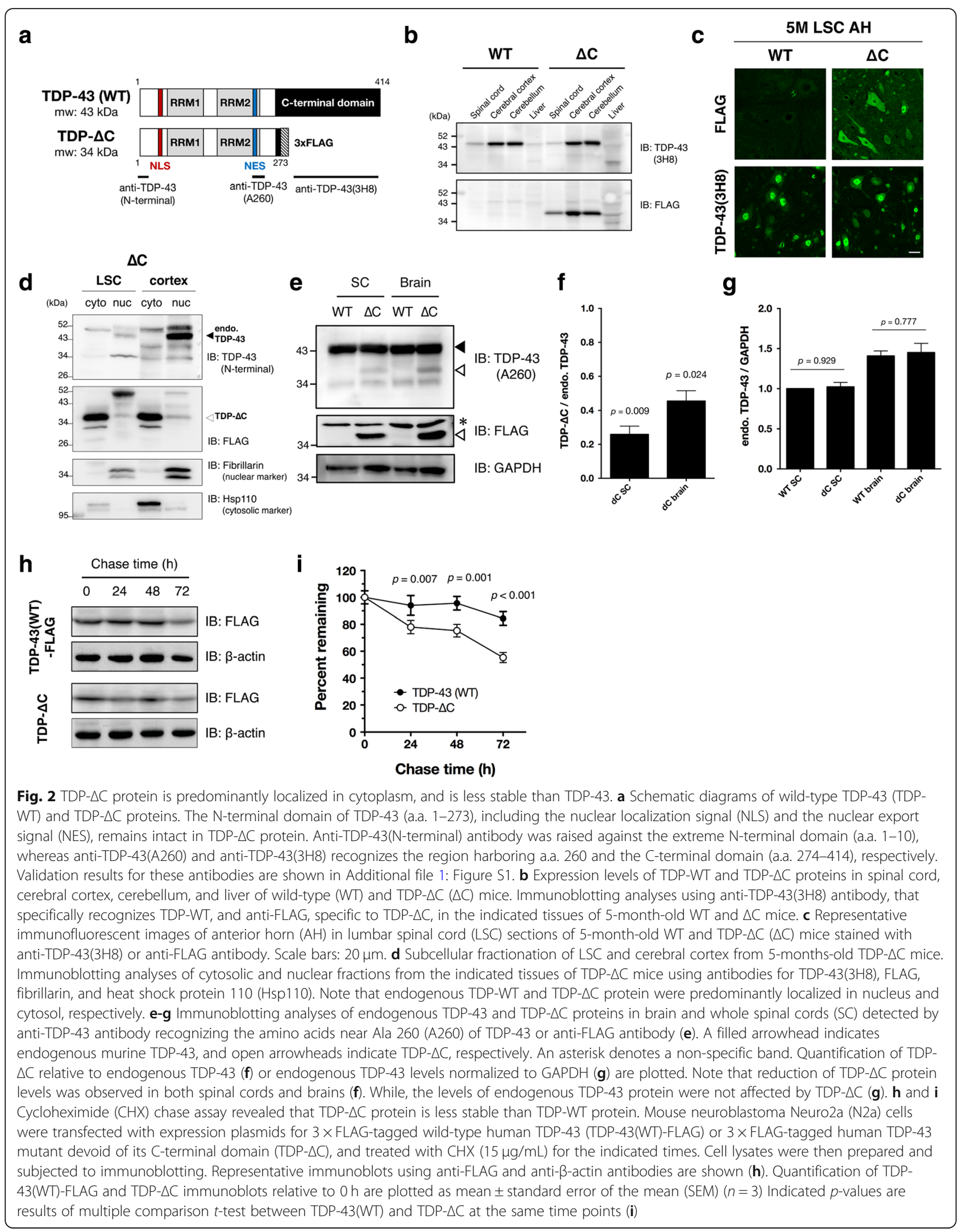


less stable than the wild-type TDP-43. Consistent with this observation, TDP- $\Delta$ C protein was degraded apparently faster than TDP-43 protein in mouse neuroblastoma Neuro2a cells as evidenced by cycloheximide (CHX) chase assay (Fig. 2h, i).

\section{TDP- $\Delta C$ mice show age-dependent mild motor dysfunction}

To examine whether there were any motor phenotypes in TDP- $\Delta \mathrm{C}$ mice, we performed a rotarod test monthly from 2 to 20 months of age (Fig. 3a). Although no difference between genotypes was detected until 18 months old, a mild but significant decline in the rotarod performance in TDP- $\Delta \mathrm{C}$ mice was observed both at 19 and 20 months old (Fig. 3a and $b$ ). This decline was observed in both genders (Additional file 1: Figure S3). As a first step to reveal the mechanistic basis for motor dysfunction in aged $\mathrm{TDP}-\Delta \mathrm{C}$ mice, we examined the $\mathrm{C}$-boutons, large cholinergic synapses terminated on $\alpha$-motor neurons, by immunofluorescence staining for staining for the presynaptic marker choline acetyltransferase (ChAT) and the post-synaptic marker $\operatorname{Kv} 2.1$ [15, 21, 49]. According to ChAT immunostaining, the number of C-boutons was substantially reduced in the lumbar spinal cord of aged TDP- $\Delta \mathrm{C}$ mice compared to agematched WTs (Fig. 3c-e). Intriguingly, while ChATpositive presynaptic boutons were reduced in number, whereas Kv2.1 labeled postsynaptic density seemed to be unchanged (Fig. 3d). Moreover, the number of ChATpositive motor neurons was unaffected (Fig. 3f), indicating that there was no detectable loss of spinal motor neurons. We also analyzed neuromuscular junctions (NMJs) of tibialis anterior muscle in aged TDP- $\Delta \mathrm{C}$ mice, however, NMJs were preserved in 700-days-old TDP- $\Delta C$ mice (Additional file 1: Figure S4). Inflammatory responses of microglia were not detectable, however, slight activation of astrocytes was observed in aged TDP- $\Delta$ C mice as evidenced by increased expression of glial fibrillary acidic protein (GFAP) (Fig. 3g). This finding may reflect the astrocytic response to the synaptic disruption of $\mathrm{C}$ boutons.

\section{Intranuclear TDP- $\Delta C$ provokes cytotoxicity in cultured neuronal cells}

We then examined whether the aberrant subcellular localization of TDP- $\Delta \mathrm{C}$ is involved in the synaptic loss observed in aged TDP- $\Delta \mathrm{C}$ mice. In TDP- $\Delta \mathrm{C}$ protein, both nuclear localization signal (NLS) and nuclear export signal (NES) are retained, which may be responsible for their subcellular localization in each compartment (Figs. 2a, 4a). In cell viability assays using Neuro2a cells, a NES-deficient TDP- $\Delta C$ variant (TDP- $\Delta \mathrm{C} \Delta \mathrm{NES}$ ) was predominantly localized in nucleus (Fig. 4a, right) and exhibited cytotoxicity at the similar level to TDP- $\Delta \mathrm{C}$, whereas a NLSdeficient TDP- $\Delta \mathrm{C}$ variant (TDP- $\Delta \mathrm{C} \Delta \mathrm{NLS}$; Fig. 4a middle) was predominantly localized in cytosol and demonstrated no cytotoxicity (Fig. 4b). Moreover, another TDP- $\Delta \mathrm{C}$ variant carrying F148 L / F149 L mutations in the RRM1 domain (TDP- $\Delta C(F / L)$ ), which is nearly devoid of its nucleotide binding ability, showed less cytotoxicity than TDP- $\Delta C$ (Fig. 4c). These results suggest that nucleotide binding ability and nuclear localization of TDP- $\Delta C$ are crucial for the age-dependent motor dysfunction in TDP- $\Delta \mathrm{C}$ mice.

\section{TDP- $\Delta C$ induces widespread perturbation of gene expression in mice}

To identify key genes linked to the motor dysfunction in TDP- $\Delta \mathrm{C}$ mice, we performed a microarray analysis using RNAs isolated from the aged TDP- $\Delta \mathrm{C}$ mouse spinal cords. We detected around 4,000 genes, of which 3,758 were upregulated (Additional file 2: Table S1) and 228 were downregulated (Additional file 3: Table S2) with foldchange $>1.2$ ( $q$-value $<0.05$ in moderate t-test) (Fig. 5a). Among these differentially expressed genes, 118 genes (91 upregulated and 27 downregulated genes) are known to be directly regulated by TDP-43 (Additional file 4: Table S3) according to the data on RNA targets of TDP-43 in primary neurons $[6,30,45]$. Representative genes from this target group are listed in Fig. 5a. Especially among these affected genes, we confirmed downregulation of Notch1 and Adarb2 in TDP- $\Delta \mathrm{C}$ mice using quantitative RT-PCR (Fig. $5 \mathrm{~b}$ ). To determine the role of TDP- $\Delta C$ in downregulation of Notch1 mRNA, we measured the mRNA level of Notch1 in Neuro2a cells with TDP-43 depletion or TDP- $\Delta$ C overexpression. Intriguingly, downregulation of Notch1 was observed in both the conditions, whereas overexpression of wild-type TDP-43 elevated the level of Notch1 mRNA (Fig. 5c).

\section{Downregulation of Notch1 is associated with suppression of Akt signaling pathway in the aged TDP- $\Delta C$ mice}

To reveal the pathomechanism common to TDP- $\Delta \mathrm{C}$ mice and sporadic ALS, we focused on 118 genes known to be regulated by TDP- 43 among the 4,000 differentially expressed genes in TDP- $\Delta C$ mice (Fig. 5a). Since TDP-43 pathology is observed in motor neurons of almost all patients with sporadic ALS, the genes directly regulated by TDP-43 are of great potential importance to understand the mechanisms for motor dysfunction and synaptic abnormality observed in TDP- $\Delta C$ mice, and may be relevant to pathogenic mechanisms for sporadic ALS.

Of these 118 genes, we focused on the Notch1mediated regulation of Akt/PKB signaling, since 
a

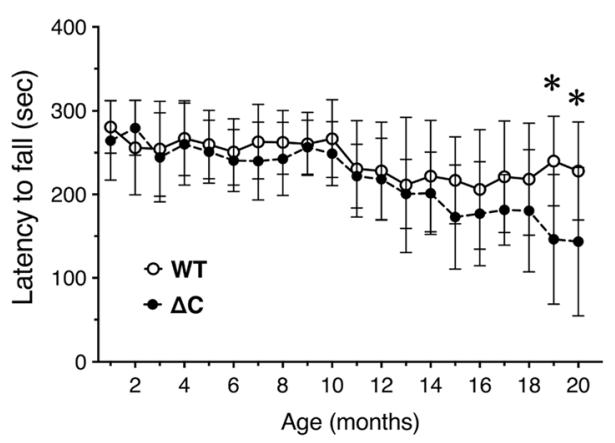

C
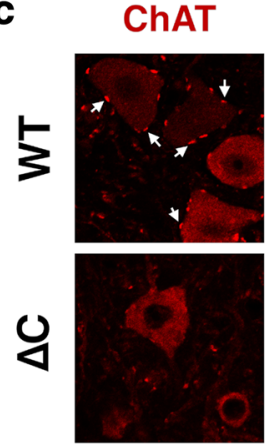

Kv2.1
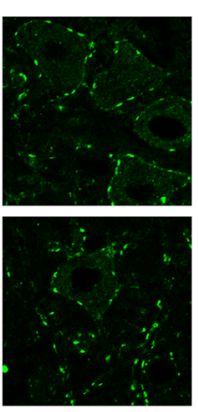

b

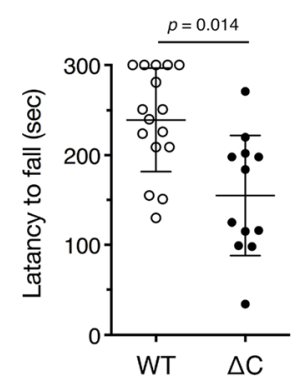

d
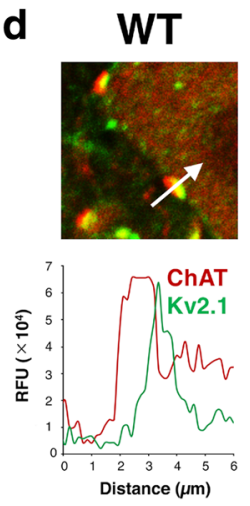

GFAP e

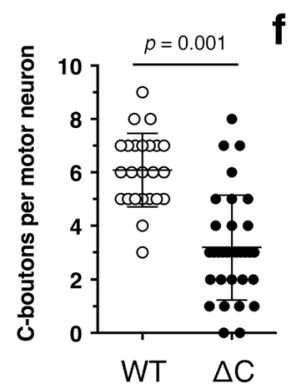

f

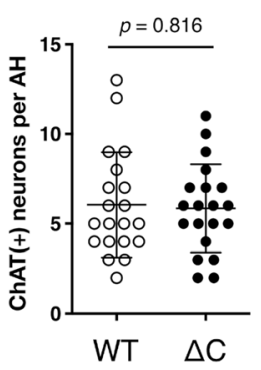

g

占

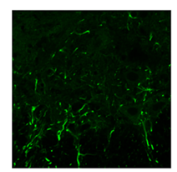

Iba-1
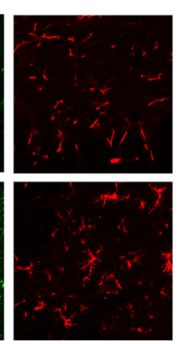

y

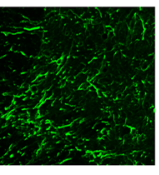

$\Delta C$
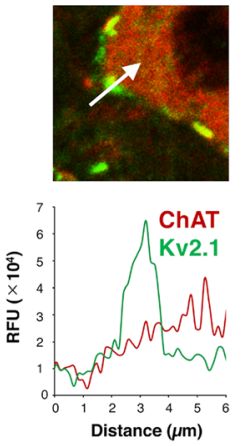

Merged

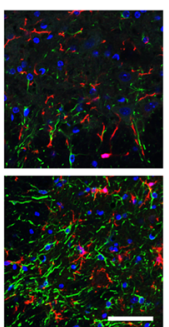

Fig. 3 TDP- $\triangle C$ knock-in mice show mild age-dependent motor dysfunction. a and b Rotarod performances of wild-type mice (WT, $n=16$ (male: 11, female: 5)) and TDP- $\Delta C$ mice ( $\Delta C, n=12$ (male: 5, female: 7)) were evaluated every month. Mean holding times on a rotating rod at the indicated ages are plotted with SD. The rotarod performance of TDP- $\triangle C$ mice did not differ from WT until 18 months of age (a), but declined substantially at 19 and 20 months old (b). Asterisks represents $p<0.05$. $\mathbf{c}$ and $\mathbf{d}$ The number of presynaptic terminals of C-boutons (C, arrows), represented by choline acetyl transferase (ChAT)-positive puncta surrounding motor neurons, was specifically reduced in 700-day-old TDP- $\triangle C$ mice (c). Representative immunofluorescence images of lumbar motor neurons with C-boutons in 700-day-old WT and TDP- $\triangle \mathrm{C}$ mice stained with antibodies for ChAT and Kv2.1 along with the merged images. Loss of ChAT immunoreactivity on the C-boutons was also confirmed by fluorescent intensity profile (d). Scale bars: $20 \mu \mathrm{m}$. e and $\mathbf{f}$ The numbers of intact C-boutons per motor neuron (e) and motor neurons per each anterior horn (AH) (f) in lumbar spinal cord (LSC) of 700-day-old WT and TDP- $\triangle C$ mice with indicated genotypes are shown. For quantification, more than 50 motor neurons (e) and $30 \mathrm{AHs}(\mathbf{f})$ in three animals per genotype were counted, and the data are plotted as mean \pm SD. $\mathbf{g}$ Gliosis of glial fibrillary acidic protein (GFAP)-positive astrocytes was slightly more intense in the LSC of 700-day-old TDP- $\triangle C$ mice compared to agematched WT. Representative immunofluorescence images of LSC sections from WT and TDP- $\triangle C$ mice stained using anti-Iba1 (microglial marker, red) and anti-GFAP (astrocytic marker, green) antibodies, along with merged images. Sections were also counterstained with DAPI staining (blue). Scale bars: $20 \mu \mathrm{m}$

alternation of Notch1 has been reported in some ALS models or patients [17, 41, 48], and Akt is tightly involved in the maintenance of synaptic integrity and motor neuron survival $[9,23,40,52]$. Molecular pathways linking Notch1 and Akt have been demonstrated in previous studies $[13,50]$ as illustrated in Fig. 7.
Briefly, Notch1 increases transcription of its downstream target Hes1, and expression of Pten, a suppressor of phosphoinositide-3-dependent Akt activation, is downregulated by Hes 1 induction. Through this pathway, therefore, Notch1 positively regulates Akt activity to maintain the synaptic integrity. We hypothesized 

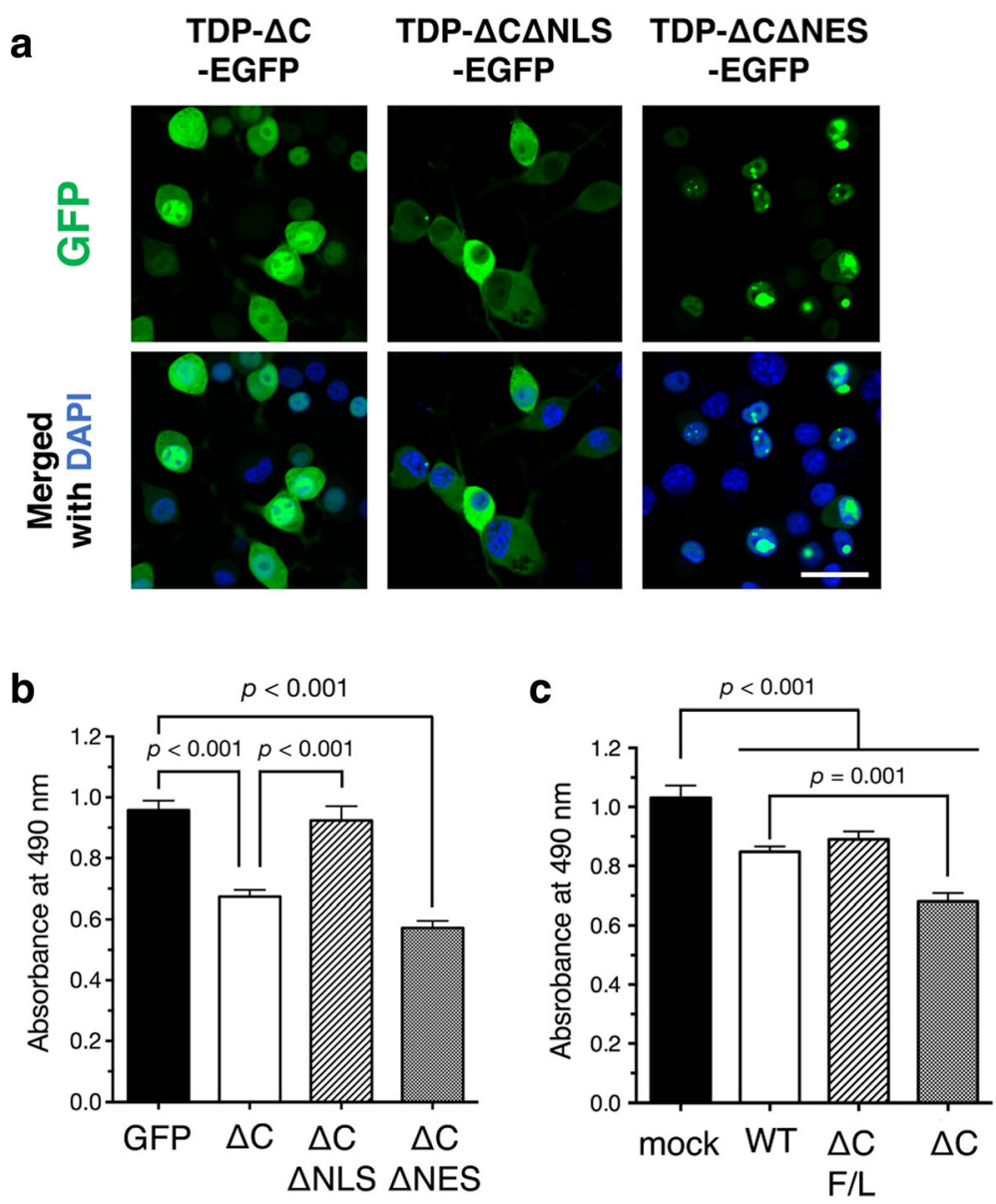

Fig. 4 Intranuclear TDP- $\triangle C$ induces cytotoxicity of cultured neuronal cells. a Representative images show subcellular localization of C-terminal EGFP-tagged TDP- $\triangle C$ (TDP- $\triangle C$-EGFP), TDP- $\triangle C$ with mutations in the NLS (TDP- $\triangle C \triangle N L S-E G F P$ ), and TDP- $\triangle C$ with mutations in the NES (TDP$\triangle C \triangle N E S-E G F P$ ) expressed in mouse neuroblastoma Neuro2a (N2a) cells as well as merged images with DAPI. Scale bar: $20 \mu \mathrm{m}$. b and $\mathbf{c}$ Nuclear localization (b) and nucleotide binding ability (c) of TDP- $\triangle$ C are crucial for cytotoxicity. N2a cells were transfected with the indicated expression plasmids and incubated for $48 \mathrm{~h}$ in the differentiation media. Cell viability was measured by MTS assay. $\Delta C \mathrm{~F} / \mathrm{L}$ represents a TDP- $\triangle C$ variant with F147 L / F149 L mutations defective in nucleotide binding. Data are expressed as mean \pm SEM of three independent experiments, each performed in triplicate

that reduced expression of Notch1 suppresses Akt activity, thereby disrupting synaptic structure in the aged TDP- $\Delta \mathrm{C}$ mice. As expected, the level of Hes1 mRNA was reduced to about $69 \%$ of WT, and Pten mRNA was reversely increased to $126 \%$ of WT in aged TDP$\Delta \mathrm{C}$ mice (Fig. 6a). The expression of phosphorylated Akt (pAkt), an active form of Akt, was substantially diminished in the spinal cord of the aged TDP- $\Delta C$ mouse (Fig. 6b). Moreover, we found that the level of pAkt was reduced in an age-dependent manner. In young TDP- $\Delta C$ mice (150 days-old), the level of pAkt did not differ from the WTs (Fig. $6 \mathrm{c}$ and d). However, a significant reduction of pAkt was observed in 400day-old (Fig. 6e and f) and 700-day-old TDP- $\Delta C$ mice (Fig. $6 \mathrm{~g}$ and $\mathrm{h}$ ). Total amounts of Akt proteins were also decreased in 700-day-old TDP- $\Delta \mathrm{C}$ mice compared to age-matched WTs, suggesting that chronic inactivation of Akt promotes degradation of Akt itself likely through a mechanism analogous to that described previously in damaged neurons [38].

\section{Discussion}

In this study, we established TDP- $\Delta \mathrm{C}$ knock-in mice, and demonstrated age-dependent motor dysfunction associated with a substantial loss of C-boutons on lumbar motor neurons. TDP- $\Delta \mathrm{C}$ deregulated numerous genes, and suppression of the Notch1-Akt signaling pathway was associated with structural abnormalities of $\mathrm{C}$ boutons. These data suggest that TDP- $\Delta \mathrm{C}$ contributes to the motor dysfunction associated with impaired NotchAkt signaling pathway (Fig. 7).

Consistent with a previous study [4], TDP- $\Delta C$ leaked from nucleus to cytosol. However, the mechanism for this nucleocytoplasmic translocation of 


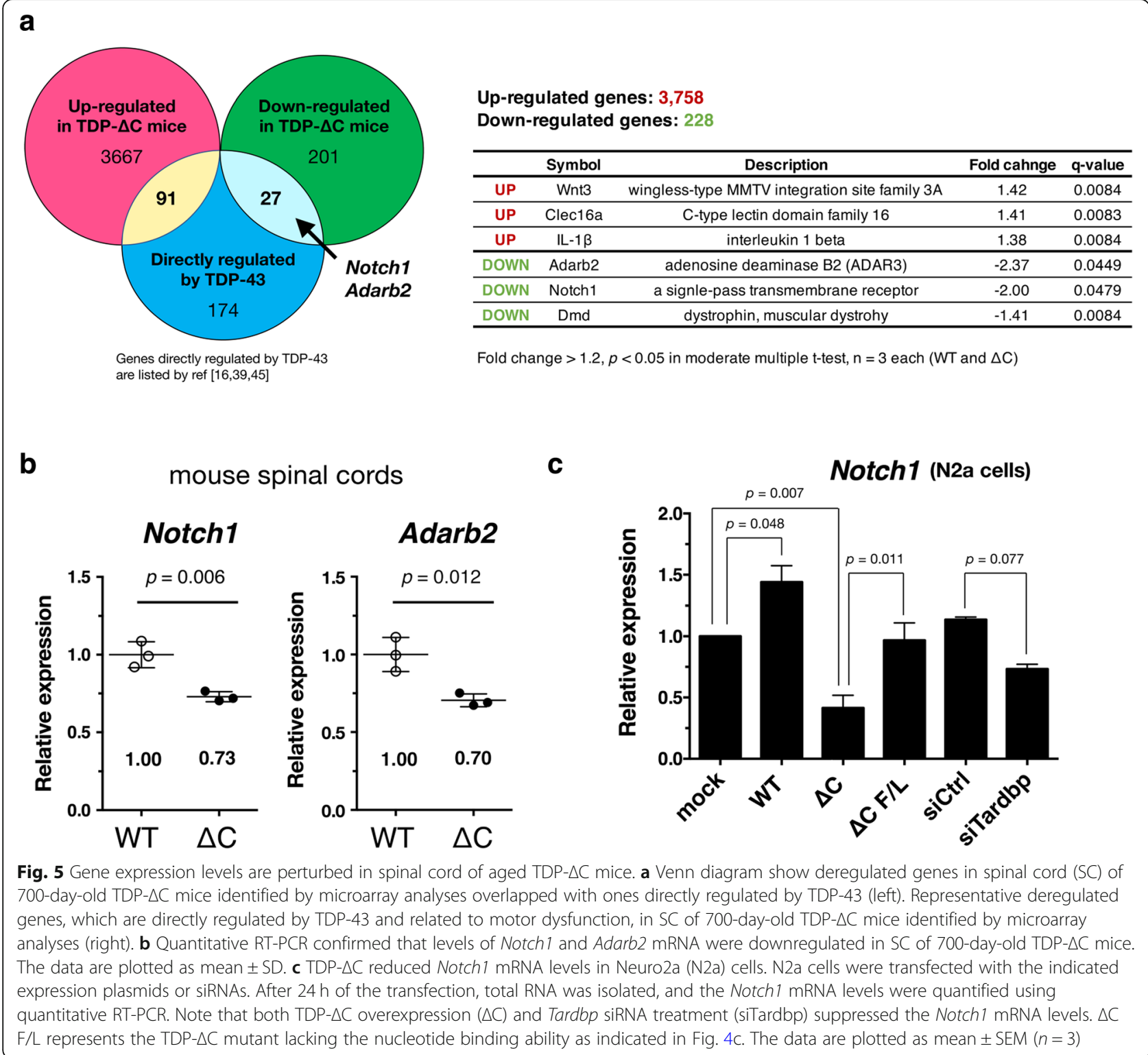

TDP-43 is controversial. One study suggested that TDP-43 translocation from nucleus to cytosol is mediated by the exportin family [3], whereas recent studies suggested that nuclear export of TDP-43 is dependent on diffusion rather than the predicted NES $[10,26]$. In the present study, GFP-fused TDP$\Delta C$, which molecular size $(\sim 70 \mathrm{kDa})$ is much larger than the average size of nuclear pore $(\sim 40 \mathrm{kDa})$, leaked from nuclei as well as FLAG-tagged TDP- $\Delta \mathrm{C}$ protein, while the TDP- $\triangle C \Delta N E S$ was retained, suggesting that the leakage of TDP- $\Delta \mathrm{C}$ is likely to be dependent on active nuclear export machinery (possibly mediated by an exportin family). Since nuclear-localized TDP- $\Delta \mathrm{C}$ exhibited cytotoxicity, clearance of TDP-43 from nuclei in ALS may be a result of cellular stress response. Future studies are required to investigate the detailed mechanisms of TDP-43 translocation.

Previous studies including ours reported a reduced number of C-boutons on motor neurons in both ALS model mice expressing mutant SOD1 [12, 15, 18] and patients with ALS $[15,22]$. Since cholinergic interneurons control the firing frequency of $\alpha$-motor neurons through C-boutons [7], a loss of C-boutons may induce hyperexcitation of $\alpha$-motor neurons leading to motor dysfunction and eventual neurodegeneration. The number of C-boutons was substantially reduced in aged TDP- $\Delta C$ mice while there was no detectable loss of spinal $\alpha$-motor neurons. Considering that a reduction of C-boutons was observed prior to the disease onset in 

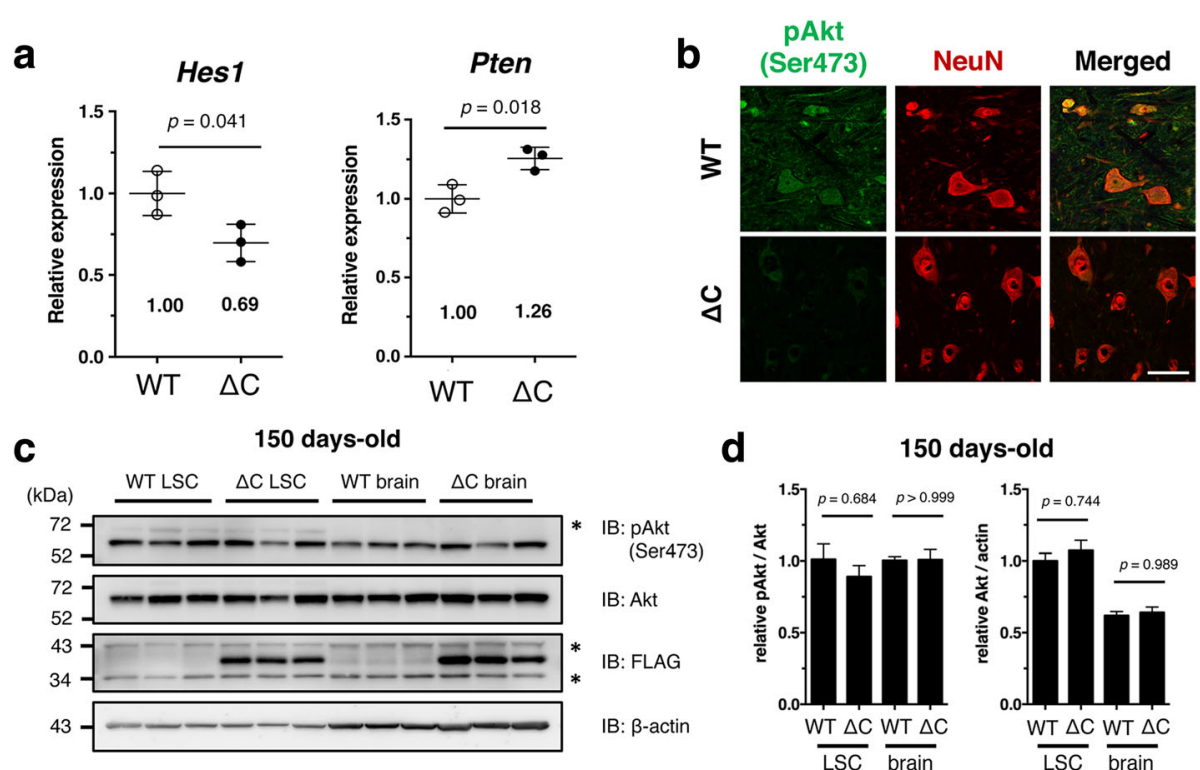

d 150 days-old
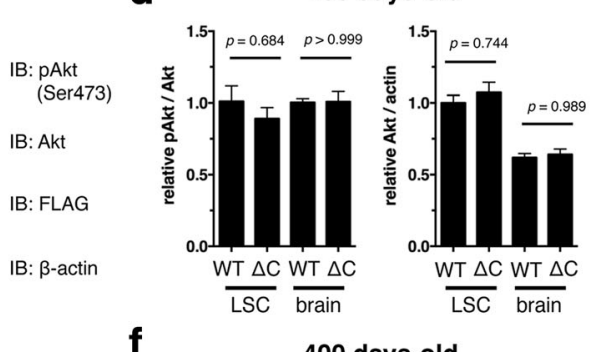

e

400 days-old

f
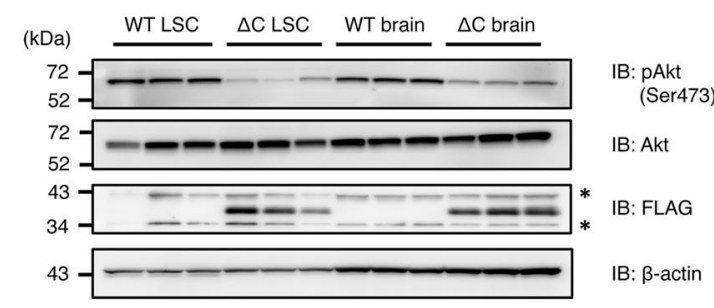

g

700 days-old

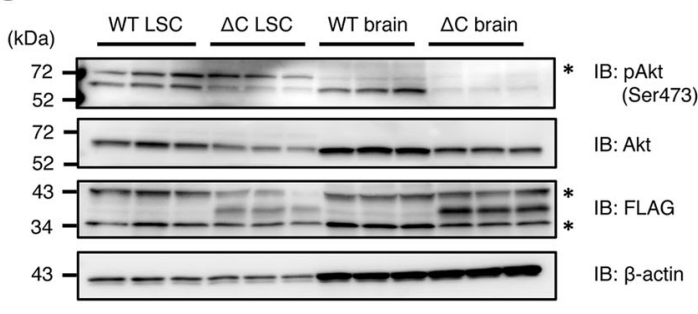

h

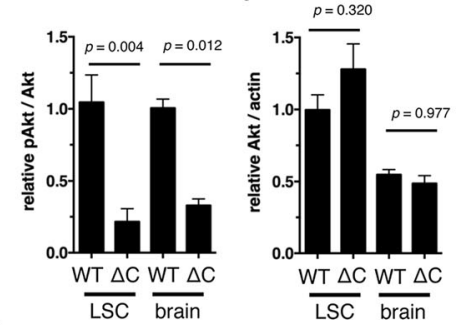

700 days-old
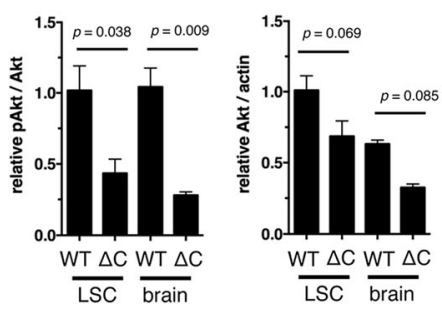

Fig. 6 Age-dependent suppression of the Akt survival pathway in brain and spinal cord of TDP- $\triangle C$ mice. a Quantitative RT-PCR confirmed downregulation of Hes1 and upregulation of Pten in spinal cord of 700-day-old TDP- $\triangle C$ ( $\Delta C$ ) mice as compared to age-matched wild-type (WT) control mice. The mRNA levels relative to WT are shown as mean \pm SD. $\mathbf{b}$ Representative images showing the lumbar spinal cord (LSC) anterior horn (AH) of WT and TDP- $\triangle \mathrm{C}$ mice at 700 days of age stained with antibodies for NeuN (red) and (active) phosphorylated-Akt (pAkt) (green) along with the merged images. Scale bar: $50 \mu \mathrm{m}$. c-h Progressive loss of active pAkt was observed in LSC and brain of TDP- $\triangle C$ mice. Nervous tissues of WT or TDP- $\triangle \mathrm{C}$ mice at the indicated ages were analyzed by immunoblotting $(\mathbf{c}, \mathbf{e}, \mathbf{g})$. Band intensities were semi-quantified using $\beta$-actin as an internal control and the relative ratios of pAkt/Akt (left panel) and Akt/Actin (right panel) are plotted $(\mathbf{d}, \mathbf{f}, \mathbf{h})$. Asterisks are non-specific bands. The data are shown as mean \pm SEM $(n=3)$

the studies using SOD1 mice $[12,15,18]$, TDP- $\Delta \mathrm{C}$-mediated neurotoxicity may not be sufficient to induce a substantial loss of $\alpha$-motor neurons within the two-year lifespan of mice. Furthermore, NMJs of TDP- $\Delta C$ mice were relatively preserved, suggesting the possibility that dysfunction of C-boutons is the earliest neuropathological phenotype in motor dysfunction related to TDP43. The molecular basis for this selective loss of C- boutons in aged TDP- $\Delta \mathrm{C}$ mice requires further investigation.

TDP- $\Delta$ C perturbed the expression levels of around 4, 000 genes in mouse spinal cords; unexpectedly, however, a limited number of these genes are regulated by TDP43 according to the studies screening for its neuronal RNA targets [6, 30, 45]. While on the other hand, nuclear-localized TDP- $\Delta C$ was sufficient to induce 


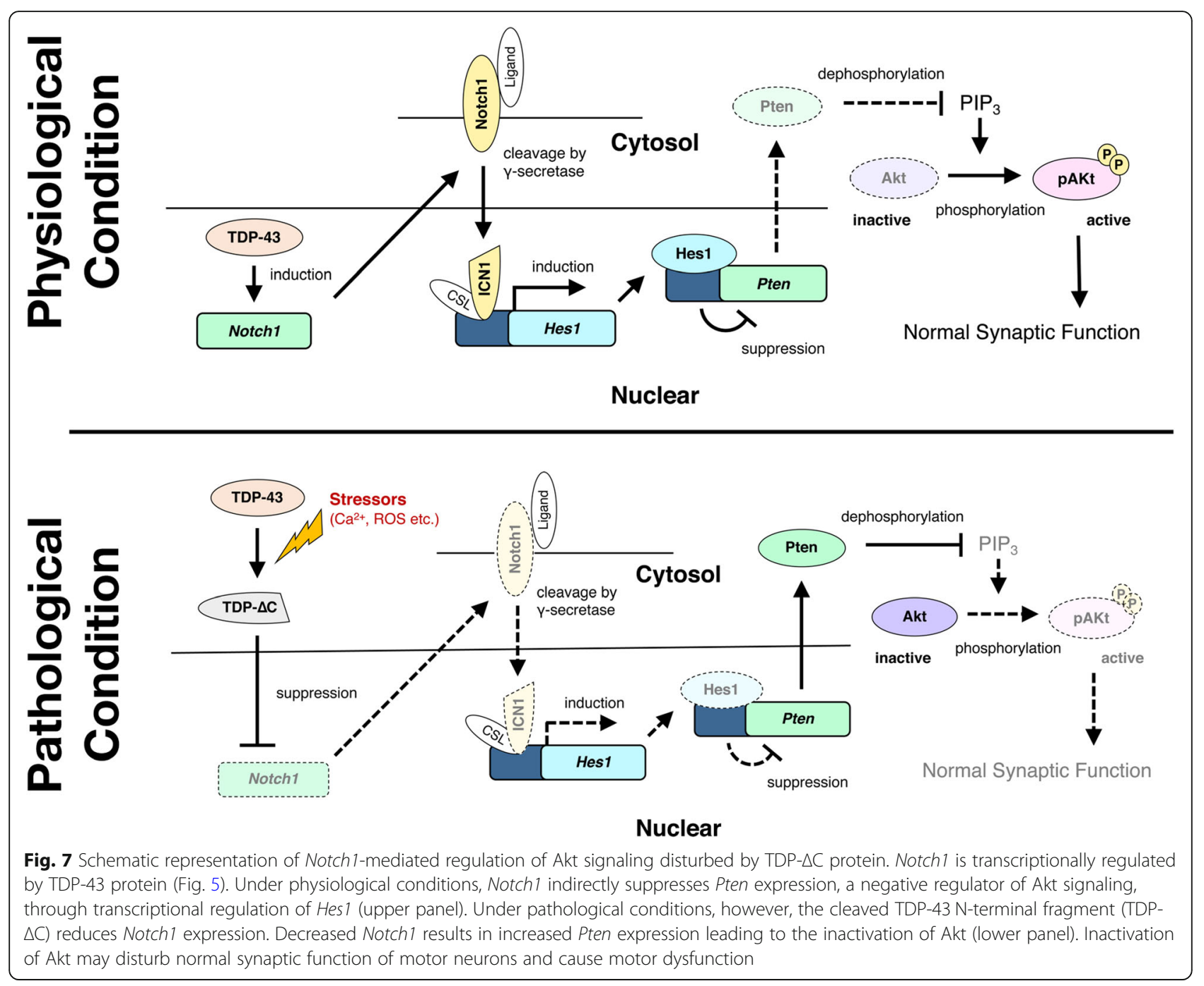

cytotoxicity. These findings suggest that TDP- $\Delta C$ evokes neurotoxicity not simply by inhibiting the functions of TDP-43. More importantly, our results suggest that TDP-43 N-terminal fragments are not merely innocuous byproducts of cleaved TDP-43 proteins, but are key elements to induce neurotoxicity. Intriguingly, mild motor dysfunction similar to the one observed in TDP- $\Delta C$ mice was also observed in Tardbp heterozygous knockout mice generated by a gene-trap insertion strategy [14] or Tardbp ${ }^{\mathrm{Q} 101 \mathrm{X}}$ heterozygous knock-in mice generated by an $\mathrm{N}$-ethyl - $\mathrm{N}$-nitrosourea (ENU) induced mutagenesis [28]. In these mice, as similar to TDP- $\Delta C$ mice, the $\mathrm{N}$-terminal fragments of TDP-43 were additionally expressed without affecting the levels of endogenous WT TDP-43, supporting the notion that the N-terminal fragments of TDP-43 are involved in age-dependent motor dysfunction in mice. Although many previous studies have identified the $\mathrm{C}$-terminal fragment of TDP-43 as a core component of TDP-43 protein aggregates, recent studies have revealed that the
TDP-43 N-terminal region promotes dimerization of TDP-43 protein [1, 29, 39]. Further, our studies and those of others have strongly implicated TDP- $43 \mathrm{~N}$ terminal fragments in ALS pathogenesis [31, 46].

Among deregulated genes in aged TDP- $\Delta \mathrm{C}$ mouse spinal cord, we identified downregulation of Notch1 Akt signaling genes during age-dependent motor dysfunction. Moreover, we found that the levels of pAkt and total Akt gradually decreased with age in the nervous tissue of TDP- $\Delta \mathrm{C}$ mice. Although direct evidence for the link between chronic downregulation of pAkt and age-dependent motor dysfunction in TDP- $\Delta \mathrm{C}$ mice was not provided in this study, there are several studies suggesting the potential role of impaired Akt signaling in ALS pathomechanisms. Indeed, reduced Notch1 signaling was also observed in a C9orf72-linked ALS model [48]. The Pten-Akt axis was disrupted by the C9orf72related (G4C2) RNA repeat, and partial depletion of Pten ameliorated the repeat-mediated toxicity [32]. Moreover, reduced Akt signaling was also reported in SOD1- 
related ALS models $[8,42]$. We found that expression of the Notch1 was also reduced by siRNA-mediated depletion of TDP-43 in cultured neuronal cells, a finding potentially relevant to sporadic ALS characterized by a loss of nuclear TDP-43. Although one study showed that TDP-43 or mutant SOD1 overexpression resulted in neurodegeneration through hyperactive Notch1 signaling [41], most of studies cited here are consistent with our findings, suggesting that insufficient Notch1-Akt signaling may lead to neurotoxicity and motor neuron dysfunction in ALS.

\section{Conclusions}

Gene ablation of the TDP-43 C-terminal domain in mice (TDP- $\Delta \mathrm{C}$ mice) induced age-dependent motor dysfunction associated with loss of cholinergic synapses on spinal $\alpha$-motor neurons. This age-dependent motor impairment was also associated with suppression of Notch1-Akt signaling pathway. Our data uncovered a detrimental role of $\mathrm{N}$-terminal TDP-43 fragments in ALS pathology in mice, associated with suppression of Akt surviving signal.

\section{Additional files}

Additional file 1: Figure S1. Complete deletion of C-terminal domain from TDP-43 induced severe neurotoxicity in cultured neuronal cells. Figure S2. Anti-TDP-43(3H8) recognizes C-terminal domain of TDP-43. Figure S3. No gender differences were found in rotarod scores in aged WT and TDP- $\Delta C$ mice. Figure S4. Neuromuscular junction (NMJ) was not affected in aged TDP- $\triangle C$ mice. (PDF $893 \mathrm{~kb}$ )

Additional file 2: Table S1. Genes upregulated (> 1.2 fold) in 700-dayold TDP- $\triangle C$ mouse spinal cord. (XLSX $499 \mathrm{~kb})$

Additional file 3: Table S2. Genes downregulated ( $>-1.2$ fold) in 700day-old TDP- $\triangle C$ mouse spinal cord. (XLSX $41 \mathrm{~kb}$ )

Additional file 4: Table S3. Affected genes ( $>1.2$ or $<-1.2$ fold) among known TDP-43 regulatory targets in 700-day-old TDP- $\triangle C$ mouse spinal cord. (XLSX $20 \mathrm{~kb})$

\section{Abbreviations}

ALS: Amyotrophic lateral sclerosis; FTLD: Frontotemporal lobar degeneration; NES: Nuclear export signal; NLS: Nuclear localization signal; SOD1: Cu/Zn superoxide dismutase; TDP-43: TAR DNA-binding protein 43

\section{Acknowledgements}

We thank RIKEN Center for Brain Science RRD for support on microarray analyses and antibody production, Center for Gene Research, Nagoya University for sequence analyses, and Center for Animal Research and Education (CARE), Nagoya University for technical support on animal experiments.

\section{Authors' contributions}

$\mathrm{KN}, \mathrm{SW}$, and $\mathrm{KY}$ designed the study. KN, SW, YM, KO, and AM performed the experiments with support from OK and FE under the supervision of KY. MA and KS established the TDP- $\triangle \mathrm{C}$ mice. SJ and HT performed the initial characterization of the mice. KN, SW, and KY interpreted the data, and wrote the manuscript. All the authors approved the manuscript.

\section{Funding}

This work was supported by Grants-in-Aid for Scientific Research $18 \mathrm{H} 02740$ and $18 \mathrm{H} 04860$ (to KY), and $17 \mathrm{H} 04986$ (to SW) from the Ministry of Education, Culture, Sports, Science and Technology (MEXT), Japan / Japan Society for the Promotion of Science (JSPS), Uehara Memorial Foundation, and Takeda Science Foundation (to KY).

\section{Availability of data and materials}

Data, material and software information supporting the conclusions of this article are included within the article and its additional files.

\section{Ethics approval and consent to participate}

All the experiments were conducted in compliance with the ARRIVE guidelines. The experiments using genetically modified mice were approved by the Animal Care and Use Committee and the recombinant DNA experiment committee of Nagoya University (approval numbers \#19269 and $\# 143$, respectively).

\section{Competing interests}

The authors declare that they have no competing interests.

\section{Author details}

${ }^{1}$ Department of Neuroscience and Pathobiology, Research Institute of Environmental Medicine, Nagoya University, Chikusa-ku, Nagoya, Aichi 464-8601, Japan. ${ }^{2}$ Department of Neuroscience and Pathobiology, Graduate School of Medicine, Nagoya University, Nagoya, Aichi 466-8550, Japan. ${ }^{3}$ Department of Biomedical Science, Graduate School of Pharmaceutical Sciences, Nagoya City University, Nagoya, Aichi 467-8603, Japan.

${ }^{4}$ Department of Animal Model Development, Brain Research Institute, Niigata University, Niigata 951-8585, Japan. ${ }^{5}$ Cellular and Molecular Neurobiology Unit, Indian Institute of Technology Jodhpur, Jodhpur, Rajasthan 342011, India.

Received: 27 June 2019 Accepted: 18 July 2019

Published online: 25 July 2019

\section{References}

1. Afroz $T$, Hock EM, Ernst $P$, Foglieni $C$, Jambeau M, Gilhespy $L A B$, Laferriere $F$, Maniecka Z, Pluckthun A, Mittl P et al (2017) Functional and dynamic polymerization of the ALS-linked protein TDP-43 antagonizes its pathologic aggregation. Nat Commun 8:45. https://doi.org/10.1038/s41467-017-00062-0

2. Arai T, Hasegawa M, Akiyama H, Ikeda K, Nonaka T, Mori H, Mann D, Tsuchiya K, Yoshida M, Hashizume $Y$ et al (2006) TDP-43 is a component of ubiquitin-positive tau-negative inclusions in frontotemporal lobar degeneration and amyotrophic lateral sclerosis. Biochem Biophys Res Commun 351:602-611. https://doi.org/10.1016/j.bbrc.2006.10.093

3. Archbold HC, Jackson KL, Arora A, Weskamp K, Tank EM, Li X, Miguez R, Dayton RD, Tamir S, Klein RL et al (2018) TDP43 nuclear export and neurodegeneration in models of amyotrophic lateral sclerosis and frontotemporal dementia. Sci Rep 8:4606. https://doi.org/10.1038/s415 98-018-22858-w

4. Ayala YM, Zago P, D'Ambrogio A, Xu YF, Petrucelli L, Buratti E, Baralle FE (2008) Structural determinants of the cellular localization and shuttling of TDP-43. J Cell Sci 121:3778-3785. https://doi.org/10.1242/jcs.038950

5. Chen-Plotkin AS, Lee VM, Trojanowski JQ (2010) TAR DNA-binding protein 43 in neurodegenerative disease. Nat Rev Neurol 6:211-220. https://doi. org/10.1038/nrneurol.2010.18

6. Colombrita C, Onesto E, Megiorni F, Pizzuti A, Baralle FE, Buratti E, Silani V, Ratti A (2012) TDP-43 and FUS RNA-binding proteins bind distinct sets of cytoplasmic messenger RNAs and differently regulate their posttranscriptional fate in motoneuron-like cells. J Biol Chem 287:15635-15647. https://doi.org/10.1074/jbc.M111.333450

7. Deardorff AS, Romer SH, Sonner PM, Fyffe RE (2014) Swimming against the tide: investigations of the C-Bouton synapse. Front Neural Circuits 8: 106 Doi https://doi.org/10.3389/fncir.2014.00106

8. Dewil M, Lambrechts D, Sciot R, Shaw PJ, Ince PG, Robberecht W, Van den Bosch L (2007) Vascular endothelial growth factor counteracts the loss of phospho-Akt preceding motor neurone degeneration in amyotrophic lateral sclerosis. Neuropathol Appl Neurobiol 33:499-509. https://doi.org/10.1111/ j.1365-2990.2007.00850.x

9. Di Polo A (2015) Dendrite pathology and neurodegeneration: focus on mTOR. Neural Regen Res 10:559-561. https://doi.org/10.4103/16 73-5374.155421

10. Ederle H, Funk C, Abou-Ajram C, Hutten S, Funk EBE, Kehlenbach RH, Bailer SM, Dormann D (2018) Nuclear egress of TDP-43 and FUS occurs 
independently of Exportin-1/CRM1. Sci Rep 8:7084. https://doi.org/10.1038/ s41598-018-25007-5

11. Furukawa Y, Kaneko K, Watanabe S, Yamanaka K, Nukina N (2011) A seeding reaction recapitulates intracellular formation of Sarkosyl-insoluble transactivation response element (TAR) DNA-binding protein-43 inclusions. J Biol Chem 286:18664-18672.https://doi.org/10.1074/jbc.M111.231209

12. Gallart-Palau X, Tarabal O, Casanovas A, Sabado J, Correa FJ, Hereu M, Piedrafita L, Caldero J, Esquerda JE (2014) Neuregulin-1 is concentrated in the postsynaptic subsurface cistern of C-Bouton inputs to alphamotoneurons and altered during motoneuron diseases. FASEB J. https:// doi.org/10.1096/fj.13-248583

13. Hales EC, Taub JW, Matherly LH (2014) New insights into Notch1 regulation of the PI3K-AKT-mTOR1 signaling axis: targeted therapy of gamma-secretase inhibitor resistant T-cell acute lymphoblastic leukemia. Cell Signal 26:149161. https://doi.org/10.1016/j.cellsig.2013.09.021

14. Kraemer BC, Schuck T, Wheeler JM, Robinson LC, Trojanowski JQ, Lee VM, Schellenberg GD (2010) Loss of murine TDP-43 disrupts motor function and plays an essential role in embryogenesis. Acta Neuropathol 119:409-419. https://doi.org/10.1007/s00401-010-0659-0

15. Lasiene J, Komine O, Fujimori-Tonou N, Powers B, Endo F, Watanabe S, Shijie J, Ravits J, Horner P, Misawa Het al (2016) Neuregulin 1 confers neuroprotection in SOD1-linked amyotrophic lateral sclerosis mice via restoration of C-boutons of spinal motor neurons. Acta Neuropathol Commun 4: 15 Doi https://doi.org/10.1186/s40478-016-0286-7

16. Lattante S, Rouleau GA, Kabashi E (2013) TARDBP and FUS mutations associated with amyotrophic lateral sclerosis: summary and update. Hum Mutat 34:812-826. https://doi.org/10.1002/humu.22319

17. Ma X, Drannik A, Jiang F, Peterson R, Turnbull J (2017) Crosstalk between notch and sonic hedgehog signaling in a mouse model of amyotrophic lateral sclerosis. Neuroreport 28:141-148. https://doi.org/10.1097/wnr. 0000000000000725

18. Milan L, Courtand G, Cardoit L, Masmejean F, Barriere G, Cazalets JR, Garret M, Bertrand SS (2015) Age-related changes in pre- and postsynaptic Partners of the Cholinergic C-boutons in wild-type and SOD1G93A lumbar Motoneurons. PLoS One 10:e0135525. https://doi. org/10.1371/journal.pone. 0135525

19. Mishina M, Sakimura K (2007) Conditional gene targeting on the pure C57BL/6 genetic background. Neurosci Res 58:105-112. https://doi.org/10.1 016/j.neures.2007.01.004

20. Motohashi K (2015) A simple and efficient seamless DNA cloning method using SLiCE from Escherichia coli laboratory strains and its application to SLiP site-directed mutagenesis. BMC Biotechnol 15:47. https://doi.org/10.11 86/s12896-015-0162-8

21. Muennich EA, Fyffe RE (2004) Focal aggregation of voltage-gated, Kv2.1 subunit-containing, potassium channels at synaptic sites in rat spinal motoneurones. J Physiol 554:673-685. https://doi.org/10.1113/ jphysiol.2003.056192

22. Nagao M, Misawa H, Kato S, Hirai S (1998) Loss of cholinergic synapses on the spinal motor neurons of amyotrophic lateral sclerosis. J Neuropathol Exp Neurol 57:329-333

23. Namikawa K, Honma M, Abe K, Takeda M, Mansur K, Obata T, Miwa A, Okado H, Kiyama H (2000) Akt/protein kinase B prevents injuryinduced motoneuron death and accelerates axonal regeneration. J Neurosci 20:2875-2886

24. Neumann M, Sampathu DM, Kwong LK, Truax AC, Micsenyi MC, Chou TT, Bruce J, Schuck T, Grossman M, Clark CM et al (2006) Ubiquitinated TDP-43 in frontotemporal lobar degeneration and amyotrophic lateral sclerosis. Science 314:130-133. https://doi.org/10.1126/science.1134108

25. Nonaka T, Kametani F, Arai T, Akiyama H, Hasegawa M (2009) Truncation and pathogenic mutations facilitate the formation of intracellular aggregates of TDP-43. Hum Mol Genet 18:3353-3364. https://doi.org/10.1093/hmg/ddp275

26. Pinarbasi ES, Cagatay T, Fung HYJ, Li YC, Chook YM, Thomas PJ (2018) Active nuclear import and passive nuclear export are the primary determinants of TDP-43 localization. Sci Rep 8:7083. https://doi.org/10.1038/ s41598-018-25008-4

27. Ratti A, Buratti E (2016) Physiological functions and pathobiology of TDP-43 and FUS/TLS proteins. J Neurochem 138(Suppl 1):95-111. https://doi.org/1 $0.1111 /$ jnc. 13625

28. Ricketts $T$, McGoldrick P, Fratta $P$, de Oliveira HM, Kent R, Phatak V, Brandner S, Blanco G, Greensmith L, Acevedo-Arozena A et al (2014) A nonsense mutation in mouse Tardbp affects TDP43 alternative splicing activity and causes limb-clasping and body tone defects. PLoS One 9:e85962. https:// doi.org/10.1371/journal.pone.0085962

29. Sasaguri H, Chew J, XU YF, Gendron TF, Garrett A, Lee CW, Jansen-West K, Bauer PO, Perkerson EA, Tong J et al (2016) The extreme N-terminus of TDP43 mediates the cytoplasmic aggregation of TDP-43 and associated toxicity in vivo. Brain Res 1647:57-64. https://doi.org/10.1016/j.brainres.2016.04.069

30. Sephton CF, Cenik C, Kucukural A, Dammer EB, Cenik B, Han Y, Dewey CM, Roth FP, Herz J, Peng J et al (2011) Identification of neuronal RNA targets of TDP-43-containing ribonucleoprotein complexes. J Biol Chem 286:12041215. https://doi.org/10.1074/jbc.M110.190884

31. Seyfried NT, Gozal YM, Dammer EB, Xia Q, Duong DM, Cheng D, Lah JJ, Levey Al, Peng J (2010) Multiplex SILAC analysis of a cellular TDP-43 proteinopathy model reveals protein inclusions associated with SUMOylation and diverse polyubiquitin chains. Mol Cell Proteomics 9:705718. https://doi.org/10.1074/mcp.M800390-MCP200

32. Stopford MJ, Higginbottom A, Hautbergue GM, Cooper-Knock J, Mulcahy PJ, De Vos KJ, Renton AE, Pliner H, Calvo A, Chio A et al (2017) C9ORF72 hexanucleotide repeat exerts toxicity in a stable, inducible motor neuronal cell model, which is rescued by partial depletion of Pten. Hum Mol Genet 26:1133-1145. https://doi.org/10.1093/hmg/dd×022

33. Taylor JP, Brown RH Jr, Cleveland DW (2016) Decoding ALS: from genes to mechanism. Nature 539:197-206. https://doi.org/10.1038/nature20413

34. Tsuiji H, Iguchi Y, Furuya A, Kataoka A, Hatsuta H, Atsuta N, Tanaka F, Hashizume Y, Akatsu H, Murayama S et al (2013) Spliceosome integrity is defective in the motor neuron diseases ALS and SMA. EMBO Mol Med 5: 221-234. https://doi.org/10.1002/emmm.201202303

35. Tsuji H, Arai T, Kametani F, Nonaka T, Yamashita M, Suzukake M, Hosokawa M, Yoshida M, Hatsuta H, Takao M et al (2012) Molecular analysis and biochemical classification of TDP-43 proteinopathy. Brain 135:3380-3391. https://doi.org/10.1093/brain/aws230

36. Udan M, Baloh RH (2011) Implications of the prion-related $\mathrm{Q} / \mathrm{N}$ domains in TDP-43 and FUS. Prion 5:1-5

37. van Es MA, Hardiman O, Chio A, Al-Chalabi A, Pasterkamp RJ, Veldink JH, van den Berg LH (2017) Amyotrophic lateral sclerosis. Lancet 390:20842098. https://doi.org/10.1016/s0140-6736(17)31287-4

38. Wakatsuki S, Saitoh F, Araki T (2011) ZNRF1 promotes Wallerian degeneration by degrading AKT to induce GSK3B-dependent CRMP2 phosphorylation. Nat Cell Biol 13:1415-1423. https://doi.org/10.1038/ncb2373

39. Wang A, Conicella AE, Schmidt HB, Martin EW, Rhoads SN, Reeb AN, Nourse A, Ramirez Montero D, Ryan VH, Rohatgi R et al (2018) A single N-terminal phosphomimic disrupts TDP-43 polymerization, phase separation, and RNA splicing. EMBO J 37. https://doi.org/10.15252/embj.201797452

40. Wang Q, Liu L, Pei L, Ju W, Ahmadian G, Lu J, Wang Y, Liu F, Wang YT (2003) Control of synaptic strength, a novel function of Akt. Neuron 38:915928. https://doi.org/10.1016/s0896-6273(03)00356-8

41. Wang $S Y$, Ren $M$, Jiang $H Z$, Wang J, Jiang $H Q$, Yin X, Qi Y, Wang XD, Dong GT, Wang TH et al (2015) Notch pathway is activated in cell culture and mouse models of mutant SOD1-related familial amyotrophic lateral sclerosis, with suppression of its activation as an additional mechanism of neuroprotection for lithium and valproate. Neuroscience 301:276-288. https://doi.org/10.1016/j.neuroscience.2015.06.002

42. Warita H, Manabe Y, Murakami T, Shiro Y, Nagano I, Abe K (2001) Early decrease of survival signal-related proteins in spinal motor neurons of presymptomatic transgenic mice with a mutant SOD1 gene. Apoptosis 6:345-352

43. Watanabe S, Hayakawa T, Wakasugi K, Yamanaka K (2014) Cystatin C protects neuronal cells against mutant copper-zinc superoxide dismutase-mediated toxicity. Cell Death Dis 5:e1497. https://doi.org/1 $0.1038 /$ cddis.2014.459

44. Watanabe $\mathrm{S}$, llieva H, Tamada H, Nomura H, Komine O, Endo F, Jin S, Mancias P, Kiyama H, Yamanaka K (2016) Mitochondria-associated membrane collapse is a common pathomechanism in SIGMAR1- and SOD1-linked ALS. EMBO Mol Med 8:1421-1437. https://doi.org/1 0.15252/emmm.201606403

45. Xiao S, Sanelli T, Dib S, Sheps D, Findlater J, Bilbao J, Keith J, Zinman L, Rogaeva E, Robertson J (2011) RNA targets of TDP-43 identified by UV-CLIP are deregulated in ALS. Mol Cell Neurosci 47:167-180. https://doi.org/10.1016/j.mcn.2011.02.013

46. Yamashita T, Hideyama T, Hachiga K, Teramoto S, Takano J, Iwata N, Saido TC, Kwak S (2012) A role for calpain-dependent cleavage of TDP-43 in 
amyotrophic lateral sclerosis pathology. Nat Commun 3:1307. https://doi. org/10.1038/ncomms2303

47. Yamashita T, Kwak S (2014) The molecular link between inefficient GluA2 Q/ $R$ site-RNA editing and TDP-43 pathology in motor neurons of sporadic amyotrophic lateral sclerosis patients. Brain Res 1584:28-38. https://doi.org/1 0.1016/j.brainres.2013.12.011

48. Yang D, Abdallah A, Li Z, Lu Y, Almeida S, Gao F-B (2015) FTD/ALSassociated poly (GR) protein impairs the notch pathway and is recruited by poly (GA) into cytoplasmic inclusions. Acta Neuropathol 130:525-535. https://doi.org/10.1007/s00401-015-1448-6

49. Zagoraiou L, Akay T, Martin JF, Brownstone RM, Jessell TM, Miles GB (2009) A cluster of cholinergic premotor interneurons modulates mouse locomotor activity. Neuron 64:645-662. https://doi.org/10.1016/..neuron.2009.10.017

50. Zeng C, Xing R, Liu J, Xing F (2016) Role of CSL-dependent and independent notch signaling pathways in cell apoptosis. Apoptosis 21:1-12. https://doi.org/10.1007/s10495-015-1188-z

51. Zhang Y, Werling U, Edelmann W (2012) SLiCE: a novel bacterial cell extract-based DNA cloning method. Nucleic Acids Res 40:e55. https:// doi.org/10.1093/nar/gkr1288

52. Zhou H, Li XM, Meinkoth J, Pittman RN (2000) Akt regulates cell survival and apoptosis at a postmitochondrial level. J Cell Biol 151:483-494

\section{Publisher's Note}

Springer Nature remains neutral with regard to jurisdictional claims in published maps and institutional affiliations.

Ready to submit your research? Choose BMC and benefit from:

- fast, convenient online submission

- thorough peer review by experienced researchers in your field

- rapid publication on acceptance

- support for research data, including large and complex data types

- gold Open Access which fosters wider collaboration and increased citations

- maximum visibility for your research: over $100 \mathrm{M}$ website views per year

At $\mathrm{BMC}$, research is always in progress.

Learn more biomedcentral.com/submissions 